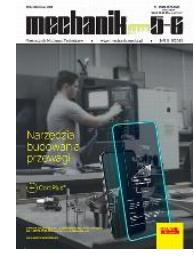

\author{
How to cite this article: \\ Authors: Jakub Kowalski, Milena Supernak-Marczewska, Krzysztof Emilianowicz, Lech Nadolny \\ Title of article: "The influence of technological errors on the corrosion degradation of the copper alloy from the cunifer \\ group - CuNi10Fe1,6Mn" \\ Mechanik, No. 5-6 (2019) \\ DOI: https://doi.org/10.17814/mechanik.2019.5-6.44
}

\title{
The influence of technological errors on the corrosion degradation of the copper alloy from the cunifer group - CuNi10Fe1,6Mn
}

\author{
JAKUB KOWALSKI \\ MILENA SUPERNAK-MARCZEWSKA \\ KRZYSZTOF EMILIANOWICZ \\ LECH NADOLNY *
}

\begin{abstract}
Dr inż. Jakub Kowalski, jakub.kowalski@pg.edu.pl, https://orcid.org/0000-0001-9603-1220 - Gdańsk University of Technology, Faculty of Ocean Engineering and Ship Technology, Department of Ship Manufacturing Technology, Quality Systems and Materials, Gdańsk, Poland

Dr inż. Milena Supernak-Marczewska, milena.supernak@pg.edu.pl, https://orcid.org/0000-0001-9800-3127 - Gdańsk University of Technology, Faculty of Ocean Engineering and Ship Technology, Department of Ship Manufacturing Technology, Quality Systems and Materials, Gdańsk, Poland

Mgr inż. Krzysztof Emilianowicz, krzysztof.emilianowicz@pg.edu.pl, https://orcid.org/0000-0002-6125-0762 - Gdańsk University of Technology, Faculty of Ocean Engineering and Ship Technology, Department of Ship Manufacturing Technology, Quality Systems and Materials, Gdańsk, Poland

Mgr inż. Lech Nadolny, lech.nadolny@pg.edu.pl, https://orcid.org/0000-0001-7301-7493 - Gdańsk University of Technology, Faculty of Ocean Engineering and Ship Technology, Department of Ship Manufacturing Technology, Quality Systems and Materials, Gdańsk, Poland
\end{abstract}

Copper and nickel alloys called cunifers ( $\mathrm{Cu}, \mathrm{Ni}$, Fe and $\mathrm{R}$ - rest of alloy elements) have found wide application in the production of ship pipeline components in contact with sea water, such as, for example, the main engine cooling system. These alloys are characterized by a very high corrosion resistance, which is ensured by appropriately carried out passivation. However, with improperly carried out passivation, this material loses its anti-corrosion properties and is often corroded. In addition, a mistakenly conducted welding process is a factor conducive to degradation processes. The purpose of this work is to show the impact of errors created during the production process and pipeline testing for its technical condition. The subject of the research was a fragment of the pipeline made of CuNi10Fe1,6Mn alloy, coming from a vessel floating on sea waters. Macro and microscopic examinations revealed a number of technological defects that affected the degradation of this element.

KEYWORDS: copper-nickels, corrosion, passivation

\section{Introduction}

Cunifers ( $\mathrm{Cu}, \mathrm{Ni}, \mathrm{Fe}$ and $\mathrm{R}$ - the rest of alloy elements) are copper alloys with nickel (with nickel content from $2 \%$ to $10 \%$ ) and alloy additives in the form of iron and other elements, e.g. manganese. These alloys are characterized by very high corrosion resistance due to the possibility of producing a tight passive layer on their surface [1] and have found wide application in the production of marine pipelines in contact with outboard water, such as the main engine cooling system or fire protection system $[2,5]$.

Corrosion resistance of copper and its alloys during operation depends on the condition and tightness of the protective oxide film [1-3]. Improving the durability of condenser installation pipes and other heat exchangers made of copper alloys is achieved by $[3,4]$ :

- reduction of cooling water aggressiveness,

- the use of appropriate alloy additives in the production of pipes,

- the use of water additives that inhibit corrosion processes,

- covering pipes with protective layers. 
Durability of pipes also depends on: technological process of production, state of the surface of the pipes produced and thermo-chemical conditions in the period of operation. These conditions affect the corrosion processes (even or local) of pipe material [4].

At the stage of the passive layer formation, the excessive speed of water flow also has a great impact on corrosion processes (excessive speed of medium flow prevents from the formation of a protective layer). However, if the passivation process is carried out incorrectly, a fragile and unstable film will be formed, which will be washed away very quickly (even if the flow rate is correct) [7]. Another factor negatively affecting the passivation process is the presence of organic substances. The presence of tight protective layers - natural or deliberately produced - has an inhibitory effect on the course of corrosive processes. There is a certain group of corrosion mechanisms that can lead to damage to the protective film and progressive destruction of the material. Such effects may be caused, for example, by the activity of bacteria in oily water. SRB bacteria in combination with aerobic bacteria form a suspension on the surface of a given fragment of the structure, which causes material degradation $[5,6,9]$.

\section{Research object}

The object of research was a fragment of the main engine refrigeration pipeline sucking outboard water from the ship (fig. 1). The entire pipeline was made of CuNi10Fe1,6Mn alloy (its chemical composition is given in tab. I). The test piece had a wall thickness of $1.5 \mathrm{~mm}$. The fragment was finished with mounting flanges.

Mounting flanges were welded using qualified technology according to PN-EN ISO 15614-6: 2008 [8]. They were made of austenitic stainless steel, the potential of which at the point of contact with the pipeline is in accordance with the standard [7].

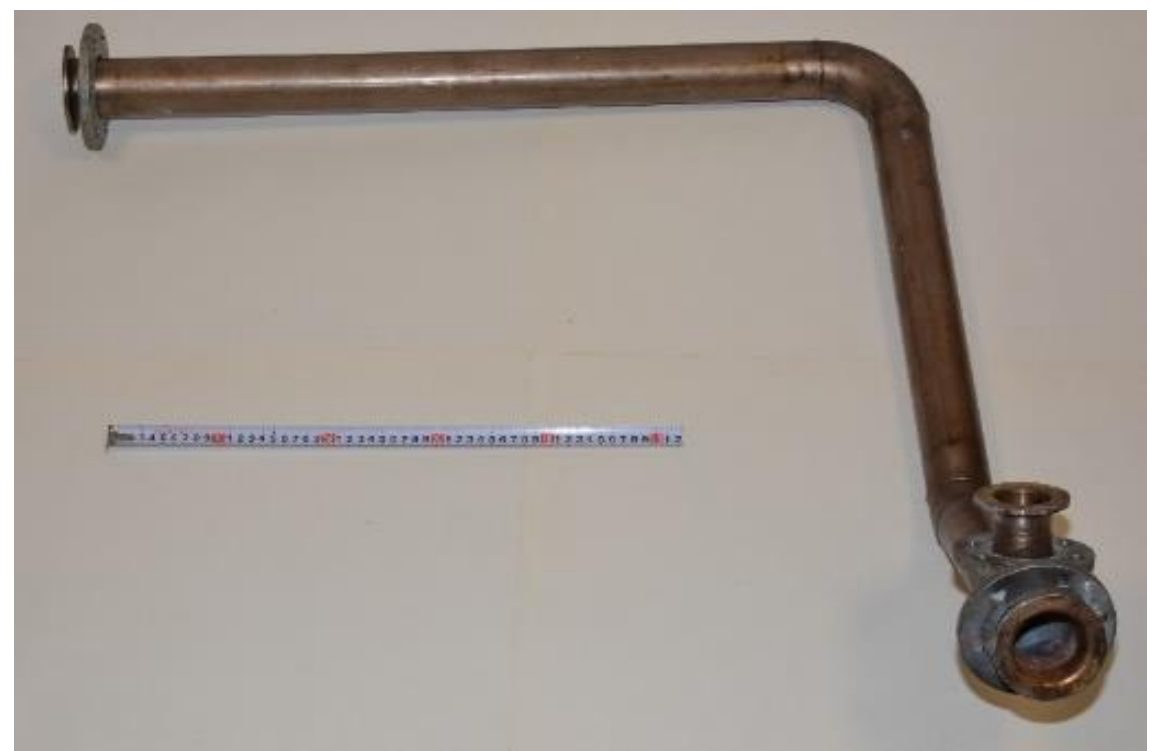

Fig. 1. Test object

TABLE I. Chemical composition of tested pipeline

\begin{tabular}{|c|c|c|c|c|c|c|c|c|c|c|}
\hline $\begin{array}{c}\text { Pipe } \\
\text { type }\end{array}$ & $\mathrm{C}[\%]$ & $\mathrm{Mn}[\%]$ & $\mathrm{P}[\%]$ & $\mathrm{S}[\%]$ & $\mathrm{Ni}[\%]$ & $\mathrm{Fe}[\%]$ & $\mathrm{Zn} \mathrm{[ \% ]}$ & $\mathrm{Zr}[\%]$ & $\mathrm{Pb}[\%]$ & $\mathrm{Cu}[\%]$ \\
\hline Type 1 & 0.0099 & 0.6424 & 0.0035 & 0.0017 & 10.4515 & 1.5347 & 0.002 & 0.0001 & 0.0038 & rest \\
\hline Type 2 & 0.0093 & 0.5114 & 0.0018 & 0.0023 & 10.3919 & 1.5034 & 0.0017 & 0.0001 & 0.0046 & rest \\
\hline Type 3 & 0.01 & 0.7225 & 0.0026 & 0.0024 & 10.6431 & 1.5683 & 0.0031 & 0.0001 & 0.003 & rest \\
\hline Type 4 & 0.017 & 0.6437 & 0.0022 & 0.0022 & 10.8699 & 1.659 & 0.0032 & 0.0001 & 0.0047 & rest \\
\hline
\end{tabular}

Considering the guidelines for the operation of cunifer pipes [7], the pipeline should be subjected to passivation with the use of chemicals, such as iron (II) sulfide or azoles (copper inhibitors - BTA/TTA/MBT), or by adding NaDDTCc (sodium dimethyldithiocarbamate), before commissioning [7]. The use of chemicals for the purpose of passivation requires good preparation and specialized service both at the preparatory stage and during the subsequent removal of the resulting process products. Pursuant to the provisions [7], a protective oxide layer may be created by flooding the pipeline installation with fresh outboard water - both salty and 
sweet. However, the process should take 14 to 90 days (the longer, the better). The literature says that better protective properties are obtained in the case of passivation by sea water [7]. The procedure itself should be carried out only once, prior to start-up, and if fresh water is used - before the first contact with sea water or etching medium. In addition, seawater can be used for both passivation and maintenance of existing coatings, while fresh water can only be used for passivation. Standard [7] advises against the use of sea water from the bay/port area, because the concentration of SRB bacteria is much higher than in the case of water from an open sea.

At the testing stage, the pipeline was flooded with sea water from the Gulf of Gdańsk. Chloride ion concentration and water $\mathrm{pH}$ were measured. The results are summarized in tab. II.

The leak test was carried out using outboard port water (oily medium and contaminated with sulfur and its compounds). Then the pipeline was left (without prior drying) for six months.

\section{TABLE II. Test results for chloride concentration and sea water reaction in the ship's area}

\begin{tabular}{|c|c|c|c|}
\hline Type of marking & Unit & Determination result & Place of sampling \\
\hline Chlorides & $\mathrm{mgCl} / \mathrm{dm}^{3}$ & 4099.2 & Ship bow region \\
\hline Chlorides & $\mathrm{mgCl} / \mathrm{dm}^{3}$ & 4014.1 & Ship stern region \\
\hline Reaction & $\mathrm{pH}$ & 7.94 & Ship bow region \\
\hline Reaction & $\mathrm{pH}$ & 7.90 & Ship stern region \\
\hline
\end{tabular}

The procedure used was inconsistent with the guidelines contained in [7], which resulted in the formation of corrosive efflorescence on the inner surface of the pipeline and a greasy slurry abundant in active SRB bacteria. It is worth mentioning that these bacteria only become active under anaerobic conditions. Sealing of the pipeline by closing it for about six months initiated the reaction of oxygen contained in the supplied water and, as a consequence, the growth and activation of bacteria. Re-mixing the anaerobic mixture with oxygenated water caused an increase in the corrosion rate of CuNi10Fe1,6Mn alloys [7]. The purpose of corrosion tests was to determine whether the pipeline in its current condition can be put into service.

\section{Research methodology}

It was assumed that the visual inspection as well as macro and microscopic examinations would be carried out as part of the research.

The first test, to determine general condition of the inner surface of the pipe and welded joints, was a visual examination with naked eye and at low magnification (25×). Hundred per cent of the internal surface and $100 \%$ of the length of welded joints were subjected to general examination. Based on the examination, places of sampling for microscopic examination were selected and the quality level of joints was assessed. Previously referenced standard [8] refers to PN-EN ISO 6520-1 $[9,10]$ as the basis for determining the type of welding incompatibilities and their quality level. It was assumed that the level of quality $\mathrm{C}$ at such a low level is acceptable.

For macroscopic examination, the pipe had to be opened (cut). The pipe was cut with a milling machine, without using a coolant to avoid soiling the internal surface. The milling machine's rotation was chosen so as not to cause excessive heating, which could affect the structure of the material.

Selected sections were carefully cut out, included, ground, polished and degreased. Then they were observed at $100 \times, 500 \times$ and $1000 \times$ magnification, under a Neophoto 2 metallographic microscope. Some of the specimens were etched for the purposes of analyzing and assessing the microstructure of the material. The E1 - iron chloride, alcohol, hydrochloric acid - was used as the etching medium - according to [11].

\section{Results}

Macroscopic examination of the inner surface of the pipe showed numerous defects and corrosive products (figs. 2 and 3). On surfaces in places where the material was in contact with the so-called standing water - e.g. in the area of the elbows, much more material degradation can be observed than in other areas (fig. 4). Tests of welded joints have shown not only local corrosion defects, but also deficiencies in penetration, cracks or residues of welding materials (fig. 5) or incomplete penetration (fig. 2), indicating the carelessness of the connections.

These welding incompatibilities are unacceptable for operational reasons. These are damages that can significantly reduce the corrosion resistance of a given material and negatively affect the service life of the pipeline element. 
After macroscopic tests, an analysis of corrosion damage and possible cracks in the microstructure was carried out. Microscopic analysis showed a large number of corrosion pits (figs. 6 and 8) and a small number of structural damage. In the vicinity of welded joints, solidified gas bubbles were observed (fig. 7). In fig. 8, where the weld microstructure is presented, a grain growth is visible, which is characteristic for places where a significant amount of heat has flowed into the material.

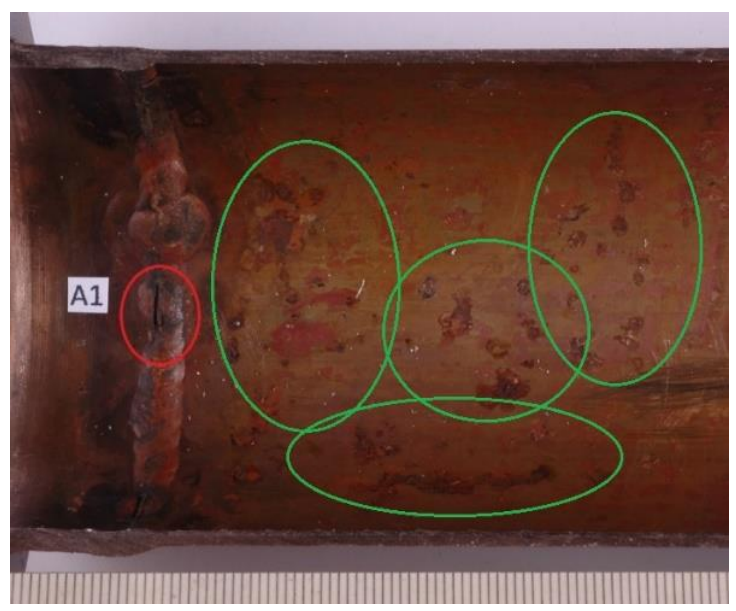

Fig. 2. Straight pipe section. Incomplete penetration [9] is marked in red, and corrosion products are marked in green

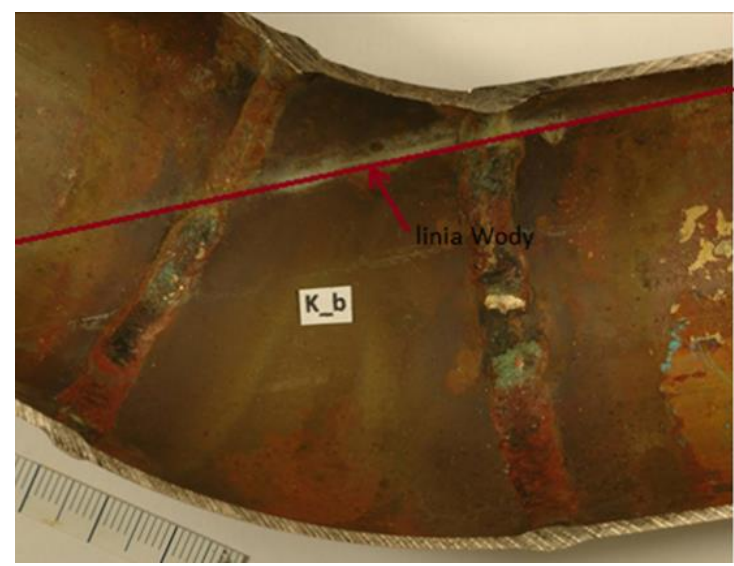

Fig. 4. Area of contact between the material and standing water (marked with a red line). Visible corrosion damage along the entire length of the section

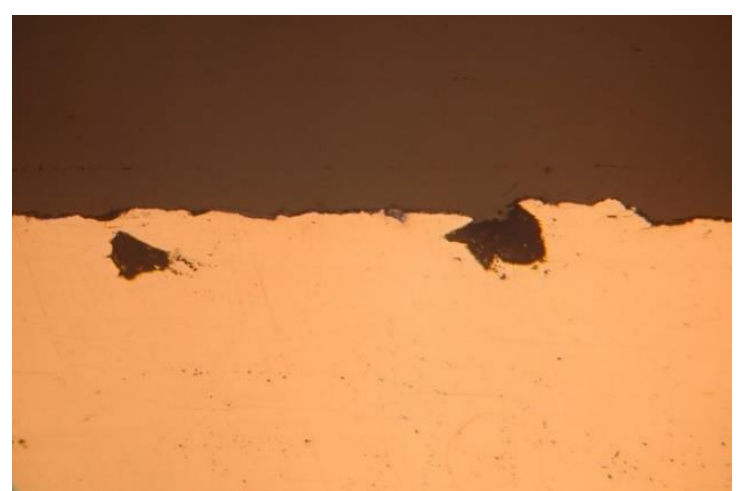

Fig. 6. Non-etched metallographic specimen (region - straight pipe section). $1000 \times$ magnification. Visible damage to the material in the form of two distinct corrosion centers

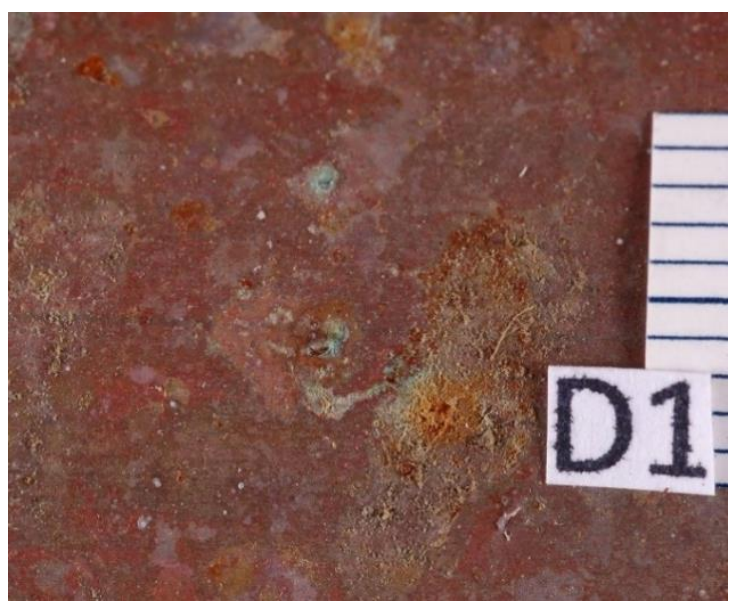

Fig. 3. The same section of the pipeline as in fig. 2 at $20 \times$ magnification. Visible corrosion products

(efflorescence) on the surface of the material

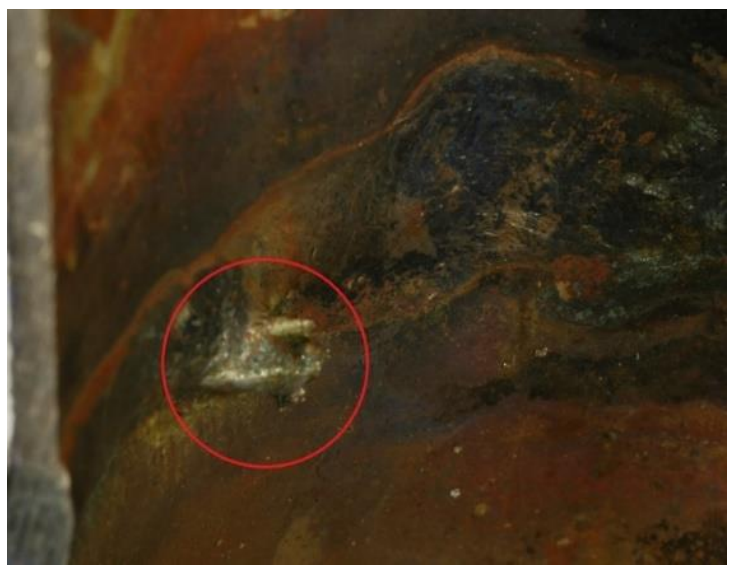

Fig. 5. Welding defect - parts of the welding electrode are visible in the weld

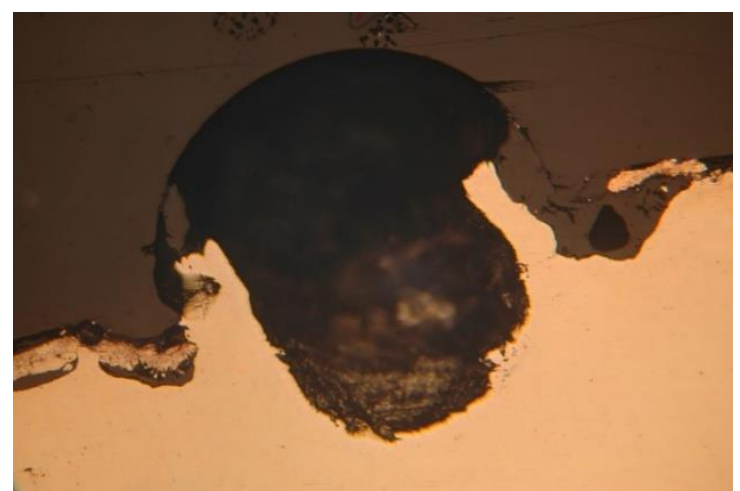

Fig. 7. Non-etched metallographic specimen (weld interior - elbow). 1000× magnification. Visible gas bubble trapped in the weld 


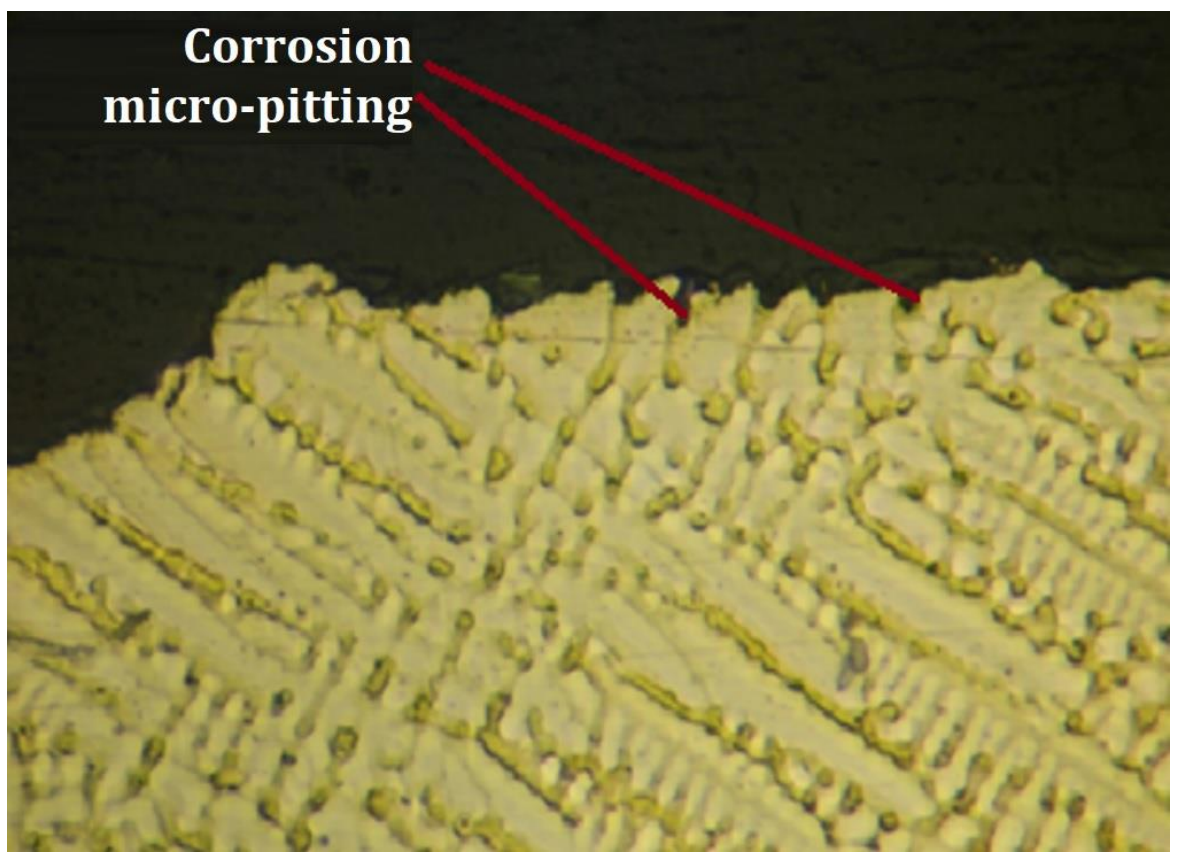

Fig. 8. Weld microstructure. 500× magnification. Small corrosion pits visible

\section{Summary}

Based on the macro and microscopic tests of the pipeline section, it was found that the condition of its internal surface was significantly damaged. This is evidenced by extensive corrosion damage such as numerous and extensive (though shallow) material losses and corrosion products present on the surface. Corrosion foci have been observed, which may indicate the beginning of corrosion propagation deep into the material. Degree of advancement of these processes makes it impossible to predict their further impact on corrosion degradation.

Incorrectly carried out passivation and errors arising during welding caused the disruption of the passive layer on the surface of the material, which caused the initiation of corrosive foci in these places. It is recommended to use a new element subjected to proper passivation.

\section{REFERENCES}

[1] Dobrzański L.A. „Materiały inżynierskie i projektowanie materiałowe. Podstawy nauki o materiałach $i$ metaloznawstwo". Warszawa: WNT, 2006.

[2] Hu S., Liu L., Cui Y., Ying L., Wang F. "Influence of hydrostatic pressure on the corrosion behavior of 90/10 coppernickel alloy tube under alternating dry and wet condition". Corrosion Science. 146 (2019): 202-212.

[3] Śliwa A., Gawron P. „Pasywacja rur mosiężnych jako sposób przeciwdziałania procesom korozyjnym na początku ich eksploatacji". Energetyka. 30 (2007): 922-925.

[4] Bala H. „Korozja materiałów - Teoria i praktyka”. Częstochowa: WIPMIES, 2002.

[5] Baszkiewicz J. „Korozja Materiałów”. Warszawa: Oficyna Wydawnicza Politechniki Warszawskiej, 2006.

[6] Traverso P., Canepa E. "A review of studies on corrosion of metals and alloys in deep-sea environment". Ocean Engineering. 87 (2014): 10-15.

[7] DIN 86004-1:2015-07 Schiffe und Meerestechnik - Korrosionsvermindernde Bauweise, Maßnahmen und Inbetriebnahme von Rohrleitungen - Teil 1: CuNiFe-Rohrleitungssysteme.

[8] PN-EN ISO 15614-6:2008 Specyfikacja i kwalifikowanie technologii spawania metali - Badanie technologii spawania - Część 6: Spawanie łukowe i gazowe miedzi i jej stopów.

[9] PN-EN ISO 6520-1:2009 Spawanie i procesy pokrewne - Klasyfikacja geometrycznych niezgodności spawalniczych w metalach - Część 1: Spawanie.

[10] PN-EN ISO 10042:2008 Spawanie - Złącza spawane łukowo w aluminium i jego stopach - Poziomy jakości dla niezgodności spawalniczych.

[11] PN-CR 12361:2002-EN Badania niszczące spoin materiałów metalowych - Odczynniki do badań makroskopowych i mikroskopowych. 